\title{
Pengaruh Media Papinka terhadap Kemampuan Menghitung Penjumlahan dan Pengurangan dalam Pembelajaran Matematika di Sekolah Dasar
}

\author{
1Midya Yuli Amreta, ${ }^{2}$ Ani Safa'ah \\ 1Universitas Nahdlatul Ulama Sunan Giri, ${ }^{2}$ SDN Kedungdowo II Bojonegoro \\ *E-mail : ${ }^{\text {midya@sunan-giri.ac.id, }{ }^{2} \text { Anisafaah200@gmail.com }}$
}

\begin{abstract}
Abstrak
Penelitianini merupakan upaya untuk mengetahui pengaruh Media PapanPintar Angka (Papinka) Terhadap Kemampuan Menghitung Penjumlahan dan Pengurangan dalam Pembelajaran Matematika di SDN Kedungdowo II, Balen, Bojonegoro. Tujuan penelitian ini adalah untuk mengetahui pelaksanaan, hasil dan pengaruh media PAPINKA terhadap kemampuan menghitung penjumlahan dan pengurangan dalam pembelajaran matematika pada siswa kelas I Sekolah Dasar Negeri Kedungdowo II, Balen, Bojonegoro. Penulis menggunakan metode wawancara (interview), dokumentasi dan angket untuk mendapatkan data yang jelas. Dalam menganalisa data penulis menggunakan teknik analisis kuantitatif meliputi uji validitas, uji reliabilitas dan uji korelasi product moment. Analisis ini didukung teknik-teknik pengumpulan data melalui penyebaran angket. Penelitian ini memperoleh hasil dengan nilai korelasi 0,750. Jika dikonsultasikan dengan tarafsignifikasi 5\% sebesar 0,468 maupun taraf signifikasi 1\% sebesar 0,590 maka terdapat pengaruh Media Papan Pintar Angka (Papinka) Terhadap Kemampuan Menghitung Penjumlahan Dan Pengurangan Dalam Pembelajaran Matematika Di SDN Kedungdowo II, Balen, Bojonegoro.
\end{abstract}

Kata kunci: Media Papan Pintar Angka (Papinka), Kemampuan Menghitung, Matematika.

\begin{abstract}
This study is an attempt to determine the effect of the Smart Numbers Board Media (Papinka) on the Ability to Calculate Addition and Subtraction in Mathematics Learning at SDN Kedungdowo II, Balen, Bojonegoro. The purpose of this study was to determine the implementation, results and influence of PAPINKA media on the ability to calculate addition and subtraction in learning mathematics in first grade students of Kedungdowo II State Elementary School, Balen, Bojonegoro. The author uses interviews (interviews), documentation and questionnaires to get clear data. In analyzing the data the author uses quantitative analysis techniques including validity, reliability and product moment correlation tests. This analysis is supported by data collection techniques through the distribution of questionnaires. This study obtained results with a correlation value of 0.750 . When consulted with a significance level of $5 \%$ of 0.468 and a significance level of $1 \%$ of 0.590 , there is an influence of the Smart Numbers Board Media (Papinka) on the Ability to Calculate Addition and Subtraction in Mathematics Learning at SDN Kedungdowo II, Balen, Bojonegoro.
\end{abstract}

Keywords: Media Smart Numbers Board (Papinka), Counting Ability, Mathematics.

https://doi.org/10.32665/jurmia.v1i1.192 This is an open-access article under the CC-BYLicense. 


\section{PENDAHULUAN}

Pendidikan memiliki peranan yang sangat penting dalam kehidupan manusia karena dapat mempengaruhi perkembangan dalam seluruh aspek kepribadian dan kehidupannya. Pendidikan berlangsung sepanjang hayat selama manusia masih mampu mengembangkan aspek kepribadian tersebut. Pendidikan disekolah dasar merupakan jenjang pendidikan yang harus ditempuh siswa sebelum melanjutkan ke jenjang SMP/SLTP dan selanjutnya ke SMA/SLTA. Pemahaman konsep di jenjang sekolah dasar harus dikuasai dengan baik karena konsep yang tertanam di sekolah dasar akan menjadi dasar dan membawa pengaruh yang sangatbesar di jenjang selanjutnya.

Mengingat peranan pendidikan di jenjang sekolah dasar sangat penting, maka penyelenggaraan pendidikan yang dilakukan di jenjang tersebut harus benar- benar diperhatikan agar tercapai kualitas pendidikan yang baik. Pengamatan dan pengalaman penulis dalam mengajar Matematika, siswa kurang mengenal tentang angka. Hal ini dilihat saat guru memberi evaluasi penjumlahan dan pengurangan,mereka masih kesulitan membedakan antara angka satu dengan yanglainnya, dan rata-rata nilai siswa masih di bawah rata-rata. Dapat dilihat dan dipahami bahwa rendahnya hasil belajar siswa disebabkan karena belumditerapkannya metode dan media pembelajaran siswa secara mandiri. Jadi guru harus mencari suatu metode atau media pembelajaran yang menarik dan menyenangkan agar siswa lebih bersemangat untuk belajar Matematika.

Kemampuan guru dalam memanfaatkan alat peraga akan menimbulkan komunikasi langsung antara siswa dengat alat peraga tersebut, dan antara siswa dengan sumber informasi atau guru secara tidak langsung. Akan tetapi faktanya masih banyak ditemui guru yang tidak memanfaatkan alat peraga dalam proses pembelajaran termasuk alat peraga IPS seperti globe, peta dan lain-lain (Suttrisno, 2021;79). Padahal sarana alat peraga tersebut disekolah telah tersedia dan hanya menjadi pajangan tanpa dimanfaatkan secara maksimal. Gagari (2010) menambahkan alat peraga mempunyai peranan penting dalam memberikan pengalaman visual kepada siswa sehingga terdorong untuk belajar serta dapat memperjelas konsep abstrak sehingga mempertinggi daya serap belajar.

Tujuan pembelajaran menghadirkan media menyajikan aktivitas-aktivitas permainan juga untuk menciptakan menarik yang mengembangkan dan mengasah terjadinya proses belajar yang bermakna. aspek-aspek perkembangan anak, meliputi Menurut Hamdani bahwa, "Media pembelajaran dalam proses belajar mengajar dapat membangkitkan keinginan dan minat afektif, kognitif, bahasa dan psikomotorik. Hal ini sesuai dengan pendapat (Hamdani, 2011) bahwa modul subtema tematik yang tersebut berisi beberapa berkaitan dengan tema yang baru, rangsangan membawa membangkitkan motivasi. Sedangkan dalam pembelajaran, guru masih terpusat atau mengacu pada modul tematik saja padahal guru bisa menggunakan media pembelajaran Papan Pintar Angka (PAPINKA).

Media papan pintar angkat adalah sebuah media pembelaajran menyusun kartu angka atau nomor. Media ini berupa permainan yang dilemparkan dengan dadu dan di hitung jumlah titik pada balok angka yang disesuaikan dengan titik dadu tersebut. Permainan dadu adalah salah satu permaian yang digemari anak-anak, media tersebut berjeniskan media visual yang hanya bisa dilihat dan dinikmati oleh indra penglihatan (Mutho'I, 2018:21).

Media Papan Pintar Angka (PAPINKA) yang terbuat dari Kertas karton. Media yang dikembangkan mengacu pada pembelajaran penjumlahan dan pengurangan. Media PAPINKA berpedoman pada prinsip "belajar sambil bermain". Media permainan ini bertujuan akan membawa anak-anak ke dunia dikarenakan media pembelajaran sebagai sumber belajar mengenai angka masih terbatas. Penyelesaian guru terhadap permasalahan yang ada belum dapat sepenuhnya membantu anak belajar mengenai 
angka secara keseluruhan. Pembelajaran angka harus menguasai bentuk tulisan angka, menyebut bunyi angka, nilai angka, urutan angka dan menulis angka. Guru biasanya menggunakanmedia modul angka dan benda-benda di sekitar belajar mereka sebagai sumber belajar angka. Oleh karena itu, untuk menyelesaikan masalah belajar angka pentingnya menghadirkan media yang sesuai dengan karakteristik anak didik. Peneliti tertarik meneliti dengan judul penelitian "Pengaruh Media Papan Pintar Angka (PAPINKA) terhadap kemampuan menghitung penjumlahan dan pengurangan dalam pembelajaran matematika di SDN Kedungdowo II, Balen, Bojonegoro".

Media adalah alat bantu atau pelengkap yang digunakan oleh guru dalam berkomunikasi dengan siswa. Media dapat berupa benda maupun prilaku. Benda dapat berupa benda langsung, seperti: daun-daunan, bunga, pensil. Dapat juga berupa benda tiruan, seperti: bola dunia, gajah- gajahan,dan dapat juga benda-benda tidak langsung seperti papan tulis, kapur, tape recorder, film dll. Suttrisno $(2021 ; 81)$ menambahkan media/alat peraga adalah segala hal yang dipilih oleh guru/pendidik untuk nanti digunakan dalam pembelajaran dengan tujuan dapat merangsang perhatian dan perasaan sehingga siswa terdorong dengan semangat dan berminat untuk mengikuti proses pembelajaran dan mempermudah guru dan siswa dalam menyajikan dan menyerap materi pelajaran. Semua itu bukan dimaksudkan untuk mengganti guru mengajar tetapi merupakan pelengkap dan membantu guru dalam mengajar serta membantu siswa dalam efektifitas pembelajaran didalam kelas. Ini berarti bahwa media merupakan peranan yang sangat penting dalam pembelajaran (Natawidjaya, 1996). Media Papan Pintar Angka (PAPINKA) adalah media pembelajaran berjenis Alat Permainan Edukatif (APE) ini berbentuk papan yang terbuat dari kertas karton. Media yang digunakan mengacu pada pembelajaran Matematika pada materi penjumlahan dan pengurangan. Media PAPINKAakan menyajikan materi angka.

Berhitung merupakan suatu hal yang berkaitan dengan perhitungan terutama menyangkut penjumlahan, pengurangan, perkalian serta pembagian. Banyak orang mempelajari berhitung karena berhitung itu diperlukan dalam pekerjaan serta kehidupan manusia, bahwa banyak orang berpendapat bahwa taraf tertentu matematika wajib dikuasai oleh semua pelajar pada semua jenis sekolah yang ada.

Berhitung bukan hanya menyuarakan bahasa tulis atau menirukan ucapan guru dengan cepat dan tepat, akan tetapi berhitung merupakan perbuatan yang dilakukan berdasarkan kerjasama beberapa keterampilan individu dalam mengamati, menyebutkan, memahami dan menulis lambang bilangan yang pasti dan sesuai dengan informasi.

Belajar adalah proses yang memungkinkan timbulnya atau berubahnya perilaku melalui reaksi terhadap situasi yang dihadapi, asalkankarakteristik perubahan itu tidak dapat dijelaskan berdasarkan kecenderungan respon alamiah,kematangan atau keadaan yang sewaktu- waktu (Sahabuddin, 2007). Hasil belajar adalah kemampuankemampuan yang telah dimiliki oleh siswa setelah ia mengalami proses belajarnya. Hal ini sesuai dengan pendapat (Firrmansyah, 2015) bahwa alam proses belajar mengajar guru melakukan tugasnya tidak hanya menyampaikan materikepada siswa, tetapi ia juga dituntut untuk membantu keberhasilan dalam menyampaikan materi pelajaran yaitu dengan cara mengevaluasi hasil belajar mengajar.

Menurut (Susanto, 2011) kemampuan berhitung dimiliki setiap anak untuk mengembangkan kemampuannya, karakteristik perkembangannya dimulai dari lingkungan yang terdekat dari dirinya sejalan dengan perkembangan yang dapat meningkat ketahap pengertian tentang jumlah yakni tentang penjumlahan dan pengurangan. Hal ini sesuai pendapat (Isnaeni, 2013) bahwa matematika adalah ilmu pengetahuan yang mengkaji konsep abstrakyang dibangun melalui proses penalaran, 
tersusun secara sistematis dan logis yang mempunyai peran penting dalam berbagai disiplin ilmu dan dapatmembantu manusia dalam memecahkan masalah sehari-hari.

Kemampuan menghitung dalam penelitian ini mengenai kemampuan numerik siswa, karena numerik adalah kemampuan hitung menghitung dengan angka-angka. Kemampuan ini dapat menunjang cara berfikir yang cepat, tepat dan cermat yang sangat mendukung keterampilan siswa dalam memahami simbol-simbol dalam matematika. Menurut Slameto (2007:14) kemampuan numerik mencakup kemampuan standar tentang bilangan, kemampuan berhitung yang mengandung penalaran dan keterampilan aljabar. Kemampuan mengopreasikan bilangan meliputi operasi hitung penjumlahan, pengurangan, perkalian dan pembagian. Berdasarkan pernyatan di atas dapat disimpulkan bahwa kemampuan menghitung (kemampuan numerik) merupakan potensi alamiah yang dimiliki seseorang dalam bidang matematika.

Uraian diatas sesuai dengan haasil penelitian oleh Mirantika, Virda. Dkk (2021:188) menyimpulkan pengembangan media PAPINKA sangat baik sesudah anak melakukan atau diberikan kegiatan bermain karenan anak-anak dapat bersosial, berinteraksi dan dapat melatih kemampuan berhitung anak usia dini dan dapat kita lihat bahwasanya anak sudah terlihat baik dalam melakukan perpmainan PAPINKA.

Pendapat tersebut juga diperkuat oleh Mutho'I, Nur Habibah (2018:21) dimana ia menyimpulkan bahwa penggunaan PAPI (Papan Pintar) dapat meningkatkan hasil belajar matematika peserta didik kelas III pada materi bangun Datar. Penggunaan media ini dinilai angat efektif digunakan di dalam kelas dalam membantu siswa melakukan pembelajaran. Dari beberapa uraian tersebut, penulis berminat untuk melakukan penelitian yang berkaitan dengan media PAPINKA di kelas.

\section{METODE PENELITIAN}

Berdasarkan judul jenis penelitian ini menggunakan pendekatan kuantitatif. Penelitian kuantitatif adalah jenis penelitian yang mengandalkan pengolahan data melalui hitungan angka dalam matematika. Penelitian kuantitatif disebut sebagai metode penelitian statistik karena menggunakan atau menerapkan rumus dan cara kerja ilmu statistic. Penelitian ini meneliti dua variabel, yaitu: Pengaruh Media Papan Pintar Angka (X) sebagai variabel independent, dan Kemampuan Menghitung Matematika Materi Penjumlahan dan Pengurangan (Y) sebagai variabel dependent. Jenis penelitian yang digunakan adalah penelitian survei. Penelitian survei adalah kegiatan penelitian yang mengumpulkan data pada saat tertentu (Darmadi, 2011).

Pengumpulan data yang digunakan pada penelitian ini menggunakan angket. Populasi dalam penelitian ini adalah seluruh siswa-siswi SDN Kedungdowo II, Balen, Bojonegoro. Sementara itu sampel yang digunakan yaitu siswa kelas I Sekolah Dasar Negeri Kedungdowo II, Balen, Bojonegoro. Uji coba instrument menggunakan bantuan SPSS 16.

Teknik analisis data dalam penelitian kuantitatif menggunakan statistic. Terdapat dua macam statistic yang digunakan untuk analisis data dalam penelitian, yaitu statistic deskriptif dan statistic infrensial. Dalam penelitian ini peneliti menggunakan teknik analisis data kuantitatif inferensial, yaitu bagian statistik yang mempelajari penafsiran dan penarikan kesimpulan yang berlaku secara umum daridata yang tersedia.

Validitas instrumen penelitian merujuk pada sejauh mana kapabilitas alat ukur penelitian menakar yang seharusnya di akar (ukur) secara benar. Sedangkan reliabilitas mengacu pada konsep ketetapan atau konsistenan hasil pengukuran. Validitas Instrumen tersebut dihitung menggunakan rumus korelasi "pearson product moment" dengan bantuan software SPSS 20.00 for Windows. Sedangkan Reliabilitas instrumen dihitung menggunakan rumus "Alpha Cronbach" dengan bantuan SPSS 20.00 for 
Windows. Setelah dinyatakan valid dan reliabel maka instrumen dapat digunakan untuk diberikan kepada siswa. Pengujian hipotesis untuk mengetahui ada tidaknya pengaruh antar variable menggunakan korelasi Product Moment.

Analisis ini untuk membuat interpretasi lebih lanjut dengan jalan membandingkan antara nilai $r$ hasil koefisien korelasi produk moment (rxy) dengan nilai $r$ tabel (rt) dalam taraf signifikansi $1 \%$ atau $5 \%$ sebagai berikut:

1) Apabila nilai rxy lebih besar dari pada rt $1 \%$ atau $5 \%$ maka hasil yang diperoleh adalah signifikan.

2) Apabila nilai rxy lebih kecil dari pada rt $1 \%$ atau $5 \%$ maka hasil yang diperoleh adalah non signifikan

\section{HASIL DAN PEMBAHASAN}

\section{Pengujian Instrumen Penelitian}

a. Uji Validitas

Tabel 4.8

Hasil uji validitas variable $\mathrm{x}$

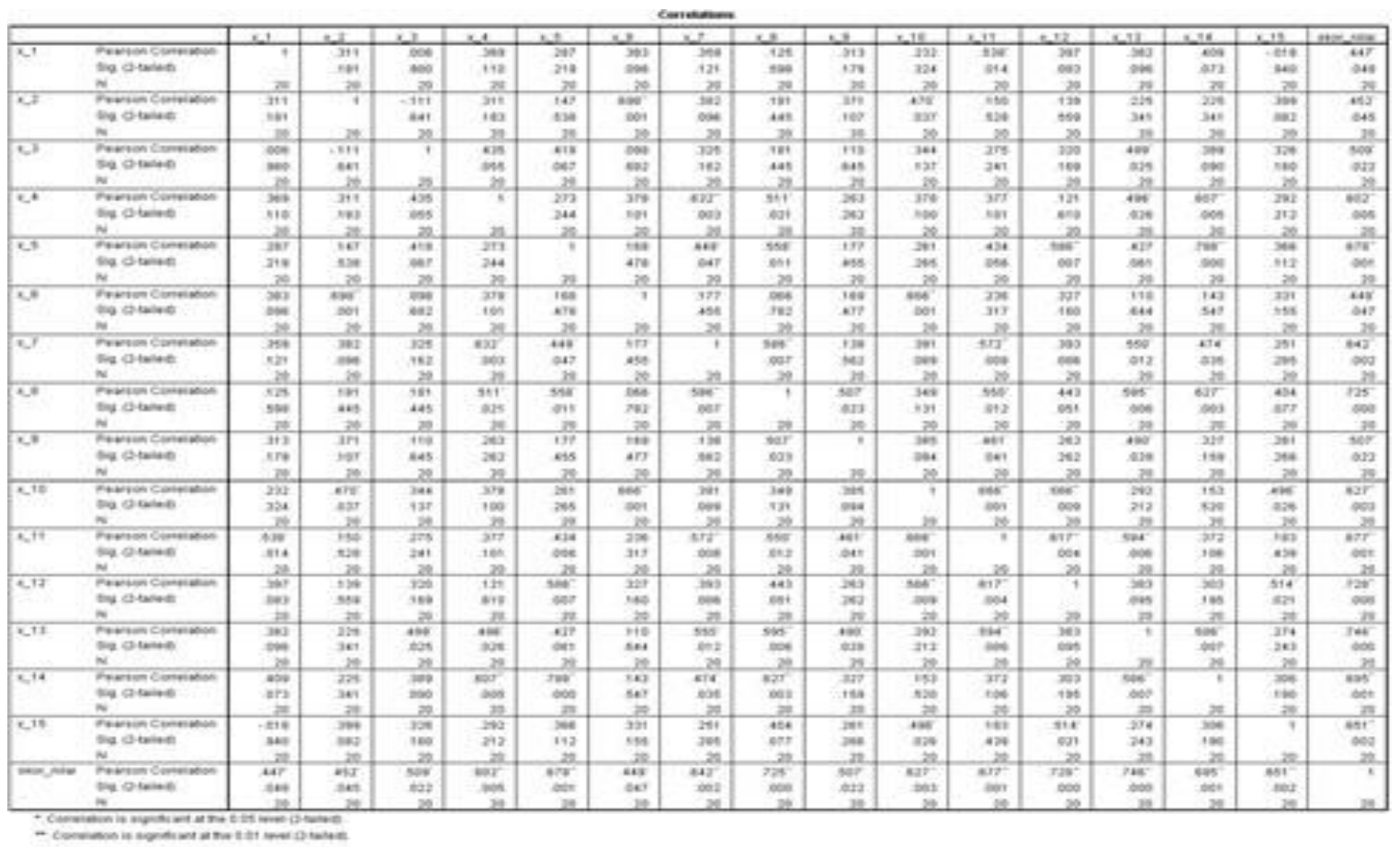

Dari data diatas dapat diketahui pada taraf signifikasi 5\% rtabeldari $\mathrm{N}=20$ adalah 0,444. Maka dapat diketahui bahwa item $1(0,447)$, item $2(0,452)$, item 3 $(0,509)$, item $4(0,602)$, dan item $5(0,678)$ item $6(0,449)$, item $7(0,642)$, item 8 $(0,725)$, item $9(0,507)$, item $10(0,627)$, item $11(0,677)$, item $12(0,728)$, item 13 $(0,746)$, item $14(0,695)$, dan item $15(0,651)$ dinyatakan valid. 


\section{Tabel 2}

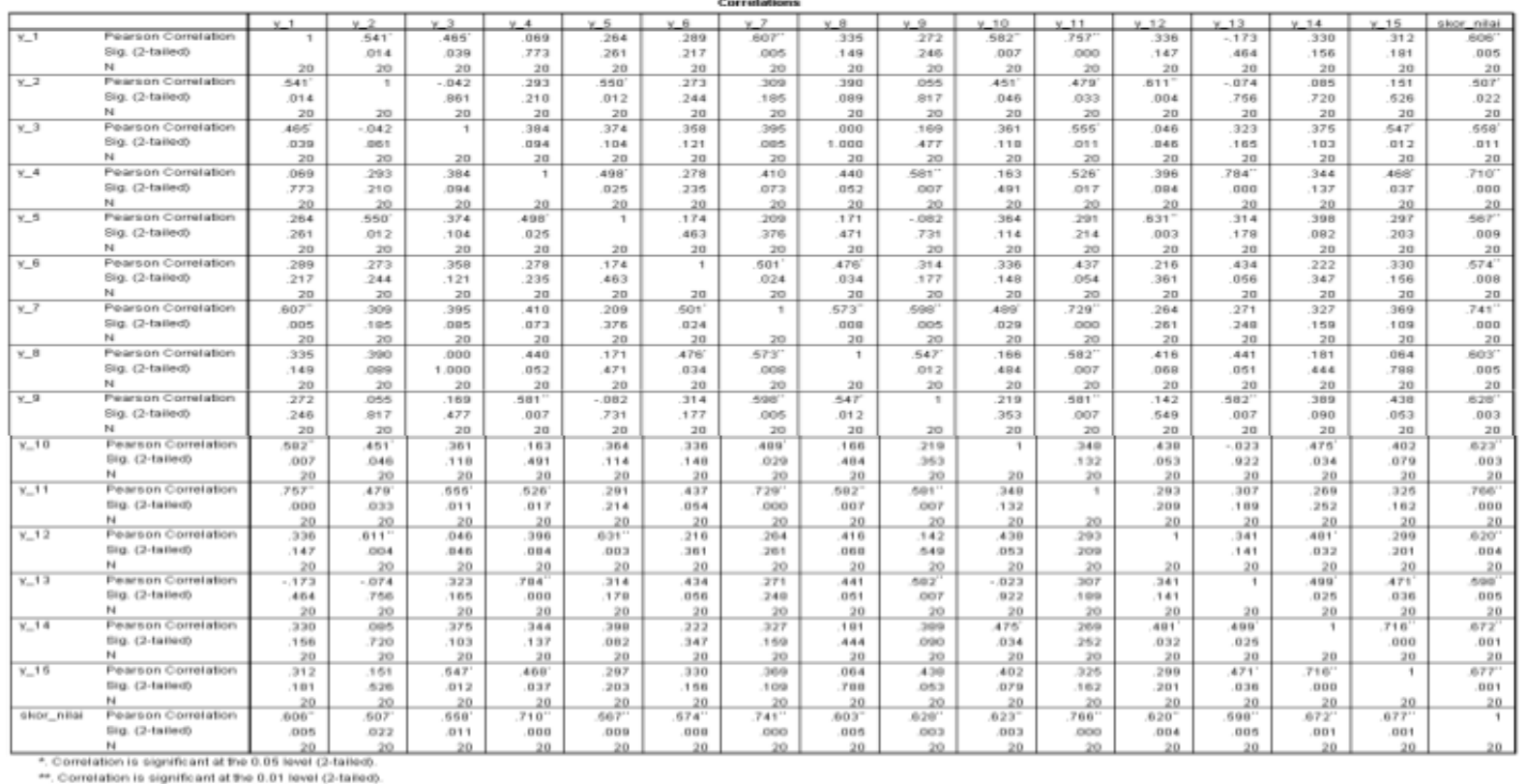

Dari data diatas dapat diketahui pada taraf signifikasi 5\% $\mathrm{r}_{\text {tabel }}$ dari $\mathrm{N}=20$ adalah 0,444 . Maka dapat diketahui bahwa item $1(0,606)$, item $2(0,507)$, item $3(0,558)$, item $4(0,710)$, item $5(0,567)$ item $6(0,574)$, item $7(0,741)$ item $8(0,603)$, item $9(0,628)$ item $10(0,623)$, item $11(0,766)$, item $12(0,620)$, item $13(0,598)$, item $14(0,672)$ item, dan item $15(0,677)$ dinyatakan valid.

b. Uji Reliabilitas

Tabel 3

Hasil Perhitungan Reliabilitas Variabel X Reliability Statistics

\begin{tabular}{cc}
$\begin{array}{c}\text { Cronbach's } \\
\text { Alpha }\end{array}$ & N of Items \\
\hline .892 & 15 \\
\hline
\end{tabular}

Dari tabel di atas dapat diketahui bahwa $\mathrm{r}_{\mathrm{h}}=0$, 892, nilai ini kemudian dibandingkan dengan ketentuan Cronbach's Alpha yaitu 0,06sehingga diperoleh hasil 0, $892 \geq 0,06$ maka item variabel X dinyatakanreliabel.

Tabel 4

Hasil Perhitungan Reliabilitas Variabel Y

Reliability Statistics

Cronbach'sAlpha $\quad \mathrm{N}$ of Items

.883

$\underline{15}$ 
Dari tabel di atas dapat diketahui bahwa $\mathrm{r}_{\mathrm{h}}=0,883$, nilai ini kemudian dibandingkan dengan ketentuan Cronbach's Alpha yaitu 0,06 sehingga diperoleh hasil $0,883 \geq 0,06$ maka item variabel $Y$ dinyatakan reliabe

c. Uji Korelasi Product Moment

Hasil analisis menggunakan korelasi Product Moment menunjukkan hasil sebesar 0,750. Sebelumnya, dicari terlebih dahulu derajat kebebasan (df), diperoleh $\mathrm{df}$ sebesar 18, selanjutnya mencari besarnya $\mathrm{r}$ yang tercantum dalam table " $r$ " product moment dengan taraf signifikasi sebesar 5\%, yaitu 0,468. Selanjutnya membandingkan $r_{x y}=0,750$ dengan $r_{\text {tabel }}=0,468$, maka dapat diketahui $r_{x y}>$ rtabel $=0,750>0,468$ sehingga dapat disimpulkan bahwa hipotesis alternative (Ha) yang berbunyi: ada Pengaruh Media PAPINKA terhadap kemampuan menghitung penjumlahan dan pengurangan pada pembelajaran Matematika pada siswa kelas I Sekolah Dasar Negeri Kedungdowo II,Balen,Bojonegoro "diterima". Dan sebaliknya hipotesis nihil (Ho) yang berbunyi: tidak ada Pengaruh Media PAPINKA terhadapkemampuan menghitung penjumlahan dan pengurangan dalam pembelajaran Matematika pada siswa kelas I Sekolah Dasar Negeri Kedungdowo II,Balen,Bojonegoro “ditolak". Artinya terdapat Pengaruh Media PAPINKA terhadap kemampuan menghitung penjumlahan dan pengurangan dalam pembelajaran Matematika pada siswa kelas I Sekolah Dasar Negeri Kedungdowo II Balen Bojonegoro.

\section{KESIMPULAN}

Berdasarkan dari hasil analisa, maka dapat ditarik kesimpulan dari analisa yang menghasilkan angka 0,750, nilai tersebut jika dibandingkan dengan nilai pada tabel sigifikasi $5 \%=0,468$ dan pada tabel signifikasi $1 \%=0,590$ maka nilai hasil perhitungan lebih besar dari pada nilai tabel yang berarti ada pengaruh. Jika diinterpretasikan pada angka indeks ' $r$ ' product moment menunjukkan besarnya antara 0,70 - 0,90 yang berarti terdapat Korelasi kuat atau tinggi. Jadi terdapat pengaruh media papinka kemampuan menghitung penjumlahan dan pengurangan dalam pembelajaran matematika di SDN Kedungdowo II Balen Bojonegoro.

\section{UCAPAN TERIMAKASIH}

Ucapan terima kasih disampaikan kepada semua pihak yang mendukung penelitian ini yakni kepala Sekolah, kelas I Sekolah Dasar Negeri Kedungdowo II Balen Bojonegoro.

\section{REFERENSI}

Darmadi, Hamid. (2011). Metode Penelitian Pendidikan, Bandung: Alfabeta

Firmansyah, Dani. (2015). Pengaruh Strategi Pembelajaran dan Minat Belajarterhadap hasil belajar Matematika, Jurnal Pendidikan,no.1

Gagari, M. Y., et al. (2010). Pengaruh penggunaan dan pemanfaatan sarana dan prasarana sekolah terhadap kinerja guru SD, SMP, SMA dan SMK. Universitas Negeri Hasanuddin.

Hamdani. (2011). Strategi Belajar Mengajar, Bandung: CV Pustaka Alfabeta

Isnaeni Nur, Faizah. (2013). Penggunaan media kartu bilangan untuk Meningkatkan Motivasi dan Hasil Belajar materi Bilangan Romawi pada siswa kelas VI, Skripsi S1 Ilmu Pendidikan, Universitas Negeri Semarang

Mirantika, Virda. Dkk. (2020). Permainan PAPINKA untuk Meningkatkan Kemampuan Berhitung Anak Usia 5-6 Tahun. Journal of Early Childhood Islamic Education. Al 
Fitrah. Vol. 3 No. 2 Januari 2020.

Mutho'I, Nur Habibah. (2018). Penggunaan Media Papi (Papan Pintar) untuk Meningktakan Hasil Belajar Matematika Peserta Didik Kelas III pada Materi Bangun Datar SDN Tanjekwagir. Journal of Indonesian Education. Vol. 1 No. 1 Desember 2018.

Natawidjaya, Rochman. ( 1997). Alat Peraga dan Komunikasi Pendidikan. Jakarta: PT Bunda Karya.

Sahabuddin. (2007). Mengajar dan Belajar Makasar: UNM.

Slameto. (2007). Belajar dan Faktor-faktor yang Mempengaruhinya. Jakarta: PT. Rineka Cipta.

Susanto Ahmad. (2011). Perkembangan Anak Usia Dini, Jakarta: Kencana.

Suttrisno, S. (2021). Pengaruh Pemanfaatan Alat Peraga Ips Terhadap Kinerja Guru Sekolah Dasar. Jurnal Ilmiah Pendidikan Dasar, 8 (1), 77-90. 